\title{
Complex Lexical Units
}




\section{Konvergenz und Divergenz}

Sprachvergleichende Studien zum Deutschen

Herausgegeben von

Eva Breindl und Lutz Gunkel

Im Auftrag des Instituts für Deutsche Sprache

\section{Gutachterrat}

Ruxandra Cosma (Bukarest), Martine Dalmas (Paris), Livio Gaeta (Turin), Matthias Hüning (Berlin), Sebastian Kürschner (Eichstätt-Ingolstadt), Torsten Leuschner (Gent), Marek Nekula (Regensburg), Attila Péteri (Budapest), Christoph Schroeder (Potsdam), Björn Wiemer (Mainz)

\section{Band 9}

INSTITUT FÜR

DEUTSCHE SPRACHE 


\section{Complex Lexical Units}

Compounds and Multi-Word Expressions

Edited by Barbara Schlücker

\section{DE GRUYTER}


Die Open-Access-Publikation dieses Bandes wurde gefördert vom Institut für Deutsche Sprache, Mannheim.

Redaktion: Dr. Anja Steinhauer

ISBN 978-3-11-063242-2

e-ISBN (PDF) 978-3-11-063244-6

e-ISBN (EPUB) 978-3-11-063253-8

\section{(c) BY-NC-ND}

This work is licensed under the Creative Commons Attribution-NonCommercial-NoDerivs 4.0 License. For details go to http://creativecommons.org/licenses/by-nc-nd/4.0/.

\section{Library of Congress Cataloging-in-Publication Data 2018964353}

\section{Bibliographic information published by the Deutsche Nationalbibliothek}

The Deutsche Nationalbibliothek lists this publication in the Deutsche Nationalbibliografie; detailed bibliographic data are available on the Internet at http://dnb.dnb.de.

(C) 2019 Barbara Schlücker, published by Walter de Gruyter GmbH, Berlin/Boston The book is published with open access at www.degruyter.com.

Typesetting: Annett Patzschewitz

Printing and binding: CPI books $\mathrm{GmbH}$, Leck

www.degruyter.com 